\title{
EVALUTION OF GERIATRIC INFECTIONS IN PALLIATIVE CARE CENTER
}

\section{Abstract}

Turkish Journal of Geriatrics DOI: 10.31086/tjgeri.2018.55 2018;21 (4):507-514

- Doğan AKDOĞAN ${ }^{1}$

- Kadriye KAHVECl ${ }^{2}$

CORRESPONDANCE

Doğan AKDOĞAN

Ankara Ulus State Hospital, Clinic Microbiology, Ankara, Turkey

\section{Phone: 03122157477}

e-mail: kahvecikadriye@gmail.com

Received: $17 / 08 / 2018$

Accepted: 02/11/2018

${ }^{1}$ Ankara Ulus State Hospital, Clinic Microbiology, Ankara, Turkey

2 Ankara Ulus State Hospital, Palliative Care, Anesthesiology and Reanimation, Ankara, Turkey
Introduction: Palliative care aims to improve quality of care by providing symptom control among geriatric patients; therefore, infection control is of utmost importance as complications increase symptom burden, thus decreasing quality of life.

Materials and Method: Medical records of patients aged $\geq 65$ years hospitalized at the palliative care center were retrospectively reviewed. Data on age, sex, diagnosis, comorbidities, length of stay, discharge status and cultures were collected.

Results: Mean age of 305 patients was $80.4 \pm 7.1$ years and length of stay was $31.1 \pm 38.1$ days. In total, 131 patients died, whereas 74 were referred to the intensive care unit, and 100 were discharged home. Main comorbidities included cerebrovascular diseases (37.4\%), cancer $(31.8 \%)$, hypertension $(40 \%)$ and diabetes mellitus $(21.3 \%)$ in patients who had dementia and Parkinson's disease. The highest growth was observed in urinary culture (67.9\%), followed by blood, wound with the least growth in the tracheal aspirate (8.2\%). E.coli was most commonly isolated in urinary, wound and tracheal aspirate culture, whereas MethicillinResistant Coagulase Negative Staphylococ was more in blood culture. While wound culture growth was less common in cancer patients, it was significantly more common in patients with Parkinson's disease, diabetes, and pressure ulcer $(p<0.05)$. Growth in the tracheal aspirate was also significantly more common in patients with hypoxic brain, percutaneous endoscopic gastrostomy, and tracheostomy $(\mathrm{p}<0.05)$.

Conclusion: Among patients receiving inpatient palliative care, bacterial growth was most common in urinary cultures, whereas it was higher in the tracheal aspirates of patients with diabetes, tracheostomy, and percutaneous endoscopic gastrostomy.

Keywords: Palliative care; Geriatrics; Infections

ARAŞTIRMA

\section{PALYATIF BAKIM MERKEZINDE GERIATRIK ENFEKSIYYONLARIN DEĞERLENDIRILMESI}

\section{$\ddot{O ̈ z}_{z}$}

Giriş: Palyatif Bakımın amacı semptom kontrolünün sağlanarak hastaların yaşam kalitesinin artırımasıdır. Geriatrik hastalar en fazla palyatif bakım ihtiyacı olan hasta grubu olması nedeniyle semptom yükünü artırarak yaşam kalitelerinin azalmasına yol açan enfeksiyonların kontrolü daha önemli hale gelmektedir.

Gereç ve Yöntem: Palyatif bakım merkezinde yatan 65 yaş ve üstü hastaların yaşı, cinsiyeti, tanıları ile eşlik eden komorbiditeleri ve kültürleri retrospektif olarak değerlendirildi.

Bulgular: Toplam 305 hastanın yaş ortalaması $80.37 \pm 7.1$ yıl, yatış süreleri $31.11 \pm 38.07$ gün idi. 131 hastanın exutus olduğu 74 hastanın yoğun bakım ünitesine çıktığı 100 hastanın da eve taburcu edildiği gözlendi. Başta serebro vasküler hastalık (\%37.37) olmak üzere, sırasıyla kanser, demans ve parkinson tanısı olan hastaların $\% 40$ da hipertansiyon \%21.31 de diyabet eşlik ettiği tespit edildi. En fazla üreme idrar kültüründe (\%67.86) olup sırasıyla kan, yara ve en azda trakeal aspirat (\%8.19) üremesi gözlendi. İdrar, yara ve trakeal aspirat kültüründe en fazla oranda E.coli izole edilirken, kan kültüründe Methicillin-Dirençli Koagulaz Negative Staphylococ daha fazla idi. Kanser hastalarında yara kültür üremesi daha düşük, parkinson, diyabet ve bası ülseri olan hastalarda yara kültürlerinde üreme oranı istatiksel olarak anlamlı derecede yüksek $(p<0.05)$ bulundu. Hipoksik beyin tanısı, perkütan endoskopik gastrostomi ve trakeostomisi olan hastalarda TA kültür üremesi istatistiksel olarak da anlamlı derecede fazla gözlendi $(p<0.05)$.

Sonuç: Palyatif bakımdaki geriatrik hastalarda en fazla yüzde ile idrar kültürlerinde üreme gözlenirken diyabeti olan trakeostomili ve perkütan endoskopik gastrostomili hastalarda trakeal aspirat üremesinin daha yüksek olduğu tespit edildi.

Anahtar sözcükler: Palyatif bakım; Geriatrik; Enfeksiyon 


\section{INTRODUCTION}

With the worldwide life expectancy increasing, chronic critical diseases associated with aging, and their symptom burden are also increasing day by day $(1,2)$. Palliative care (PC) is defined as an approach that increases the quality of life of patients/their relatives who experience difficulties due to life-threatening diseases by preventing or eliminating all physical, psychosocial, and psychological problems, especially pain, after performing early and effective assessment (3). At present, $80 \%$ of deaths occur during old age, a majority of which are in patients requiring PC in the last stages of their disease course (4). Most of the deaths are observed in individuals who are $>65$ years of age in developed countries, and as the life expectancy increases, the elderly population also increases with a relative reduction in the ratio of working population and an increasing mean age of potential caregivers. For this reason, the importance of PC is gradually becoming more acknowledged (5). In recent years, it was reported that increased health expenditures for the geriatric population with both chronic conditions and functional impairment led to the integration of geriatrics and PC implementation principles, which resulted in improved care quality and reduced use of costlier emergency services, hospitals, and nursing homes (6). It is estimated that only $14 \%$ of the 20 million patients who require $P C$ every year receive such services $(7,8)$. The effective utilization of PC services is very important given the very limited access to PC. Several studies have shown that PC-related infections prolong the length of hospitalization. The prevention of infectious diseases is of paramount importance in cancer patients receiving PC. However, little is known with regard to the factors that cause infection in these patients (9). Despite the high infection prevalence, antimicrobial therapy in the PC setting remains unclear as its indications and benefits are not well understood (10).

Furthermore, itisknownthatinfection management would be more effective with the identification of infectious agents and implementation of necessary precautions in the care of geriatric patients requiring PC. Therefore, in this study, we aimed to investigate the infections and affecting factors in the geriatric patients who were followed up in a PC setting.

\section{MATERIALS AND METHOD}

This study was performed in accordance with the Declaration of Helsinki principles after being granted an approval by the Ethics Committee of Ankara Numune Training and Research Hospital (Ankara, Turkey) in 06/07/2018 (Approval no. 1974). Medical records of patients aged $\geq 65$ years admitted at the PC Center of Ulus State Hospital between 01/01/2013 and 12/31/2017 were retrospectively examined. Patients with missing file records were excluded from the study, whereas those with growth in their cultures were included in the study. Collected data comprised information on age, sex, and presence of comorbidities or conditions including cancer, cerebrovascular disease (CVE), dementia, chronic obstructive pulmonary disease (COPD), hypoxic brain (HB), Parkinson's disease (PD), motor neuron disease(MND), heart failure (HF), hypertension (HT), diabetes mellitus (DM), percutaneous endoscopic gastrostomy (PEG), tracheostomy, and pressure ulcer (PU). The length of stay (LOS) at the PC center and discharge status [death, intensive care unit (ICU), or at home] were determined. Culture growth in blood, urine, wound, and tracheal aspirate (TA) were recorded.

\section{Statistical analysis}

In this study, the data obtained from patients hospitalized at the PC center were entered into the computerized program. Where in necessary error checks and corrections were made. Normal distribution of continuous variables (age and LOS) was graphically examined using the Kolmogorov Smirnov test. Chi-square test was employed to investigate the relationship between two independent categorical variables. Categorical variables and frequency distributions are expressed as numbers and percentages, whereas numerical variables were expressed as mean \pm standard deviation.

All statistical analyses and calculations were performed with the use of MS Excel 2010 and IBM SPSS Statistics Ver. 23.0 software (IBM Corp., Armonk, NY, USA). An overall type I error level of $95 \%$ was used to indicate statistical significance. 
Table 1. Demographic characteristics of the patients.

\begin{tabular}{|c|c|c|}
\hline Variable & & Value \\
\hline \multicolumn{3}{|c|}{ Ages (Years) * } \\
\hline & & $80.37 \pm 7.1$ \\
\hline \multicolumn{3}{|c|}{ Gender** } \\
\hline & Female & $139(45.6)$ \\
\hline & Male & $166(54.4)$ \\
\hline \multicolumn{3}{|c|}{ LOS in PCC (days)* } \\
\hline & & $31.11 \pm 38.07$ \\
\hline \multicolumn{3}{|c|}{ Discharge ${ }^{\star \star}$} \\
\hline & Exutus & $131(43.0)$ \\
\hline & Intensive Care Unit & $74(24.3)$ \\
\hline & Home & $100(32.8)$ \\
\hline \multicolumn{3}{|l|}{ Diagnosis } \\
\hline & Cancer & $97(31.80)$ \\
\hline & Cerebrovascular Disease & $114(37.37)$ \\
\hline & Dementia & 55 (18.03) \\
\hline & COPD & $26(8.52)$ \\
\hline & Hypoxic Brain & $7(2.29)$ \\
\hline & Parkinson's disease & $23(7.54)$ \\
\hline & Motor Neurone Disease & $4(1.31)$ \\
\hline & Trauma & $11(3.60)$ \\
\hline & Other & $7(2.29)$ \\
\hline \multicolumn{3}{|c|}{ Comorbidity } \\
\hline & Heart Failure & $52(17.04)$ \\
\hline & Hypertension & $122(40.00)$ \\
\hline & Diabetes Mellitus & $65(21.31)$ \\
\hline & PEG & $95(31.14)$ \\
\hline & Tracheostomy & $68(22.29)$ \\
\hline & Pressure Ulcer & 179 (58.68) \\
\hline
\end{tabular}

* Values are presented as the mean \pm standard deviation. ${ }^{*}$ Values are presented as $n(\%)$

LOS in PCC: Length of Stay in PCC; COPD: Chronic Obstructive Pulmonary Disease; PEG: Percutaneous Endoscopic Gastrostomy; 
Table 2. Culture results of patients.

\begin{tabular}{|c|c|c|c|c|}
\hline \multirow[b]{2}{*}{ Organism } & \multicolumn{4}{|c|}{ Type of culture } \\
\hline & $\begin{array}{l}\text { Urine } \\
\text { n (\%) }\end{array}$ & $\begin{array}{c}\text { Blood } \\
\text { n (\%) }\end{array}$ & $\begin{array}{r}\text { Wound } \\
\text { n (\%) }\end{array}$ & Tracheal Aspirate n (\%) \\
\hline Acinetobacter spp. & $29(14.00)$ & $20(20.40)$ & $27(29.34)$ & $6(24.00)$ \\
\hline Enterococcus spp. & $27(13.04)$ & $9(0.09)$ & $3(3.26)$ & - \\
\hline Escherichia coli & $179(86.47)$ & $70(71.42)$ & 67 (72.82) & $18(72.00)$ \\
\hline MR-CoNS & $120(5.79)$ & $80(81.63)$ & $15(16.30)$ & $4(16.00)$ \\
\hline MRSA & - & $3(3.06)$ & 8 (8.69) & $3(12.00)$ \\
\hline MS-CoNS & $3(1.44)$ & $17(17.34)$ & - & $2(8.00)$ \\
\hline MSSA & - & $9(0.09)$ & $8(8.69)$ & - \\
\hline Proteus spp. & 22 (10.62) & $4(4.08)$ & $41(44.56)$ & $3(12.00)$ \\
\hline Pseudomonas spp. & $59(28.50)$ & $14(1.28)$ & $43(46.73)$ & $15(60.00)$ \\
\hline Total of isolates $\mathbf{n}(\%)$ & $207(67.86)$ & $98(32.13)$ & $92(30.16)$ & 25 (8.19) \\
\hline
\end{tabular}

MR: Methicillin-Resistant; CoNS: Coagulase Negative Staphylococci; SA: Staphylococcus Aureus; MS: Methicillin-Sensitive

Table 3. Comparison of culture results according to discharge status of the patients.

\begin{tabular}{|c|c|c|c|c|c|c|}
\hline & & $\begin{array}{r}\text { Exutus } \\
\mathrm{n}(\%)\end{array}$ & $\begin{array}{r}\text { ICU } \\
\text { n (\%) } \\
\end{array}$ & $\begin{array}{r}\text { Home } \\
\mathrm{n}(\%)\end{array}$ & $\chi 2$ value & $p$ \\
\hline \multirow{3}{*}{ Blood } & Present & $38(26.76)$ & $66(46.48)$ & 37 (26.06) & 5.463 & 0.065 \\
\hline & Absent & $64(39.26)$ & 36 (22.09) & $63(38.65)$ & & \\
\hline & Total & $131(42.95)$ & $74(24.26)$ & 100 (32.79) & & \\
\hline \multirow{3}{*}{ Ürine } & Present & $86(41.55)$ & 48 (23.19) & 73 (35.27) & 1.81 & 0.405 \\
\hline & Absent & $45(45.92)$ & $26(26.53)$ & $27(27.55)$ & & \\
\hline & Total & 131 (42.95) & $74(24.26)$ & 100 (32.79) & & \\
\hline \multirow{3}{*}{ Wound } & Present & $36(39.13)$ & 19 (20.65) & 37 (40.22) & 3.374 & 0.185 \\
\hline & Absent & 95 (44.6) & 55 (25.82) & $63(29.58)$ & & \\
\hline & Total & $131(42.95)$ & $74(24.26)$ & 100 (32.79) & & \\
\hline \multirow{3}{*}{ Rectal } & Present & $20(37.04)$ & $12(22.22)$ & $22(40.74)$ & 1.913 & 0.384 \\
\hline & Absent & $111(44.22)$ & $62(24.7)$ & 78 (31.08) & & \\
\hline & Total & 131 (42.95) & $74(24.26)$ & 100 (32.79) & & \\
\hline \multirow{3}{*}{$\begin{array}{l}\text { Tracheal } \\
\text { Aspirate }\end{array}$} & Present & $7(28)$ & $11(44)$ & $7(28)$ & 5.98 & 0.051 \\
\hline & Absent & $124(44.29)$ & $63(22.5)$ & $93(33.21)$ & & \\
\hline & Total & $131(42.95)$ & $74(24.26)$ & 100 (32.79) & & \\
\hline
\end{tabular}

Chi-square test was used, and $p<0.05$ is significant 


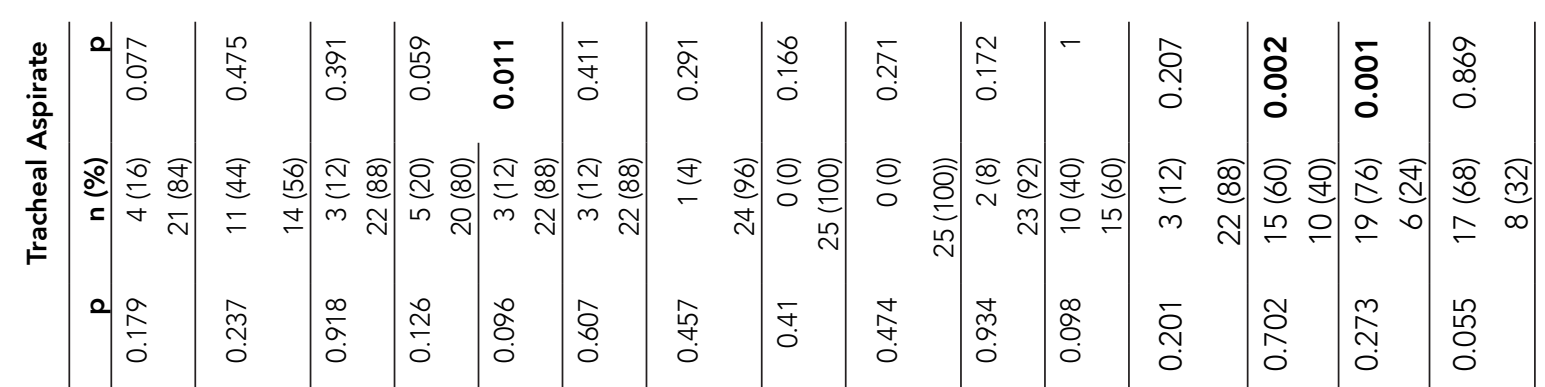

焉

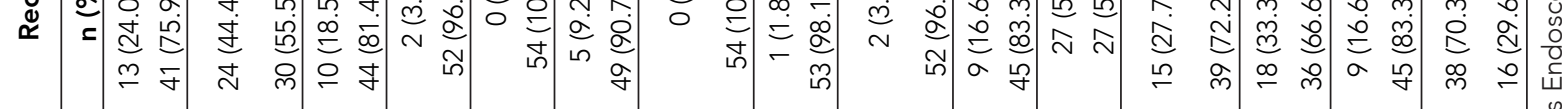

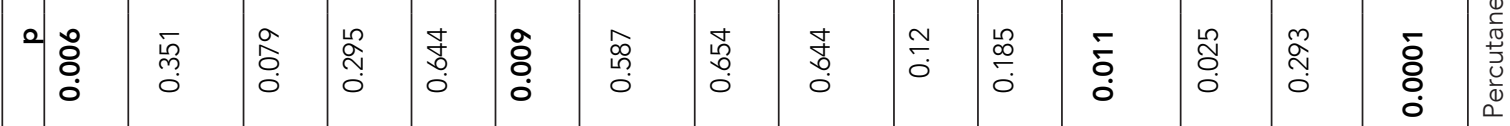

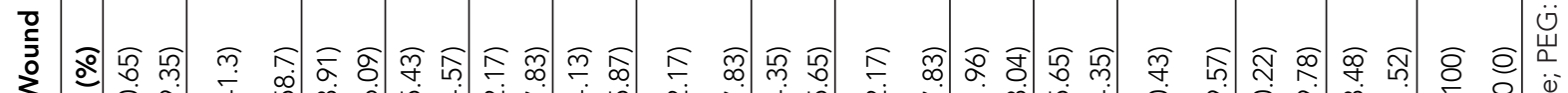

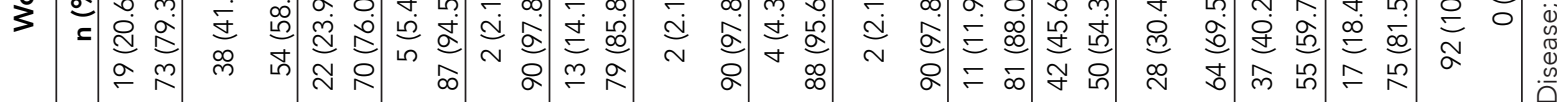

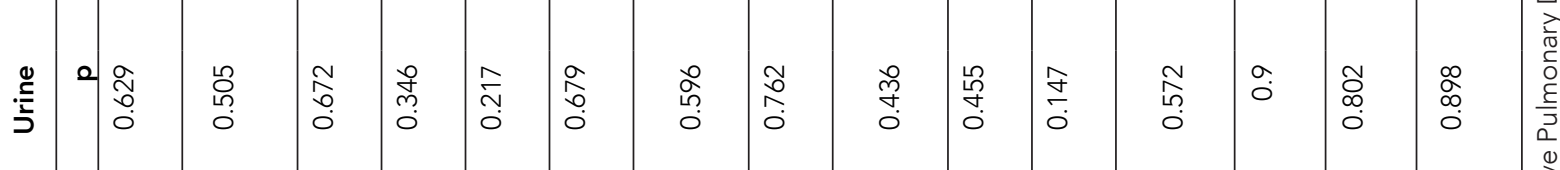

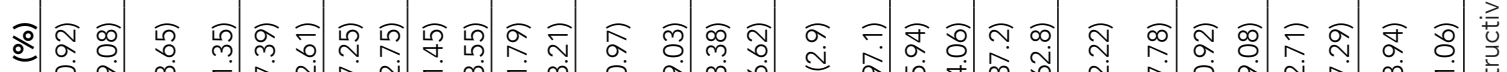

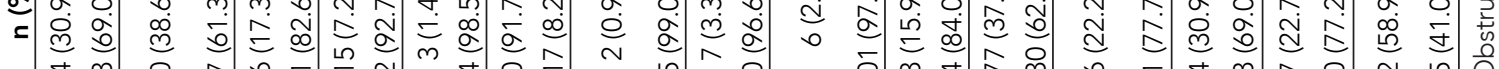

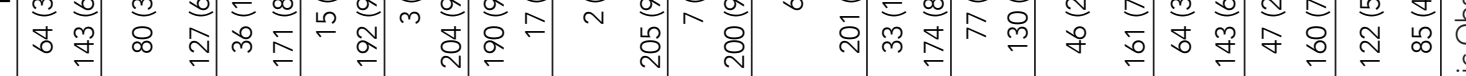

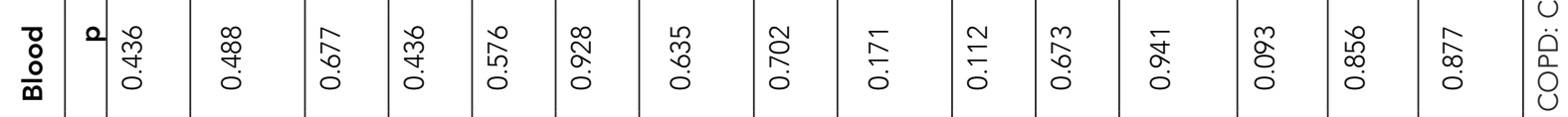

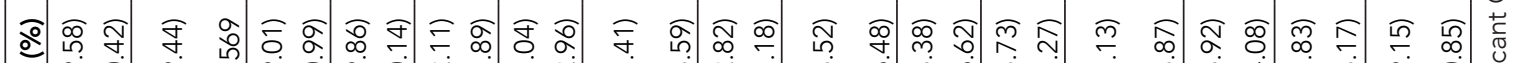

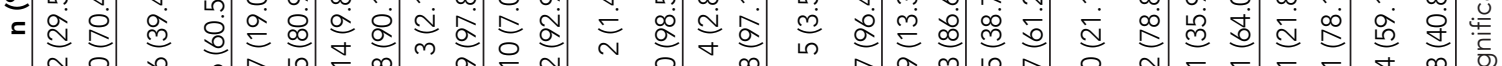

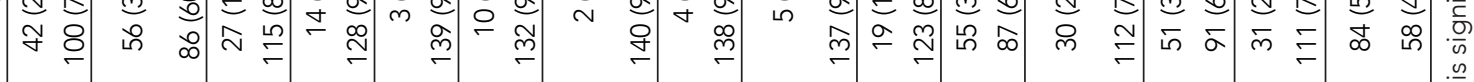

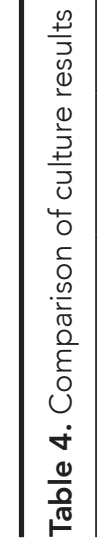

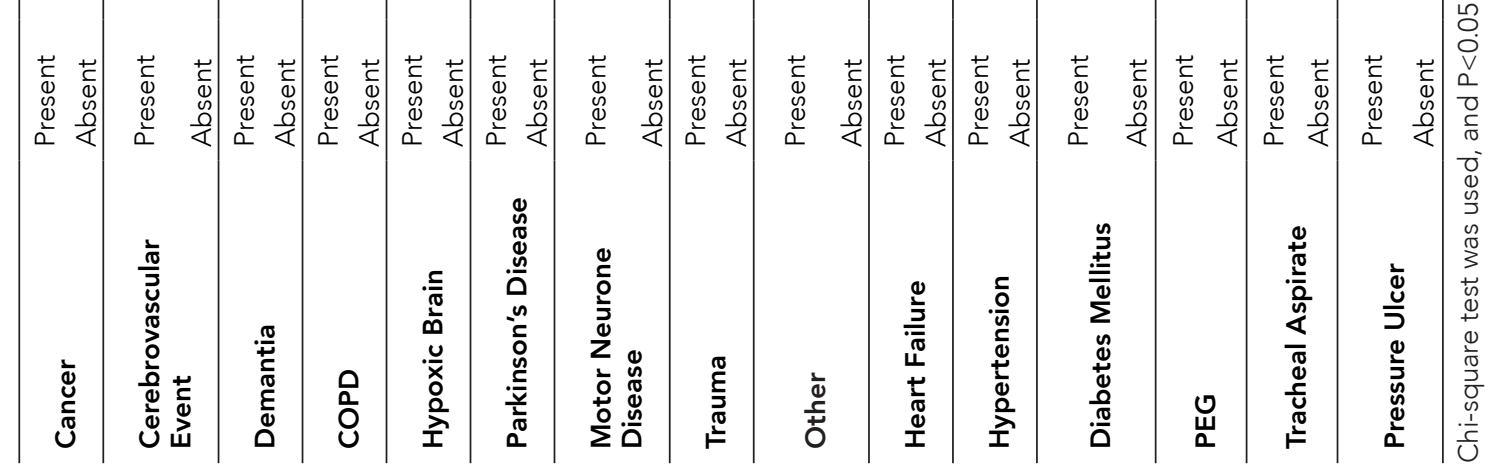




\section{RESULTS}

Medical records of patients aged $\geq 65$ years admitted at the PC Center of Ulus State Hospital between 1/01/2013 and 12/31/2017 were retrospectively examined. With the exclusion of 35 patients with missing data, a total of 305 patients who had growth in their cultures were included in the study. The mean age of the patient population, comprising 139 females and 166 males, was $80.34 \pm 7.1$ years. The LOS in PC was $31.1 \pm 38.1$ days. The distribution of patients' prognosis showed death in 131 patients, referral to ICU in 74 patients, and home discharge in 100 patients (Table 1).

The main comorbidities included CVE (37.4\%), cancer (31.8\%), HT (40\%), and DM (21.3\%) in patients who had dementia and PD. More than half of the patients (58.7\%) had PU, followed by PEG (31.1\%) and tracheostomy (22.3\%; Table 1). Growth in cultures is demonstrated in Table 2 as follows: highest growth was observed in urinary culture (67.9\%), followed by blood, wound, and the least in TA (8.2\%). E.coli was most commonly isolated in urine, wound and tracheal aspirate culture (respectively $86.5 \%$, $72.8 \%$, 72.0\%) whereas Methicillin-Resistant (MR) Coagulase Negative Staphylococci (CoNS) was more in blood culture (81.6\%). When the prognosis of the patients was compared by the growth in their cultured specimens, growth was most likely to be observed in the blood culture (37\%) of patients referred to the ICU, whereas growth in urinary culture was higher $(n=86,41.6 \%)$ in cases that resulted in death, albeit not statistically significant $(p=0,065)$ (Table 3). The growth in cultures was also compared in terms of the patients' diagnosis (Table 4). While wound culture growth was less common in cancer patients, it was significantly more common in patients with $P D, D M$, and $P U(p<0.05)$. Growth in TA was also significantly more common in patients with $\mathrm{HB}, \mathrm{PEG}$, and tracheostomy $(p<0.05)$.

\section{DISCUSSION}

Patients requiring $\mathrm{PC}$, especially those in the terminal stage, are very susceptible to infections, with the symptom burden from these infections further reducing their quality of life (11). The main purpose of $P C$ is to improve the quality of life of patients by providing symptom control (12). Infection control becomes a top priority as the geriatric population is the group of patients with the greatest need for PC, whereby the emergence of particularly resistant bacterial strains and infection control measures may result in additional burden on the patients and their family $(13,14)$. In our study, we found that among geriatric patients receiving $P C$, the most common condition was urinary tract infections, and growth in TA was more frequent in diabetic patients with PEG and tracheostomy. Bacterial growth was observed in urine cultures of 207 out of 305 patients. Consistent with our results, a study performed in a PC unit reported growth in cultures from the urinary tract (42.5\%), respiratory tract $(22.9 \%)$, blood $(12.5 \%)$, and skin and subcutaneous tissues (12.5\%) (11). In our study, growth in urinary culture was $67.9 \%$, in blood culture $32.1 \%$, and in wound culture $30.2 \%$. Pereira et al. (15) reported a retrospective chart review of the prevalence of infections in 100 consecutive admissions to palliative care unit. There were 74 infections in 55 patients, with urinary tract, respiratory tract, skin and subcutaneous tissue, blood, and mouth as the most common infection sites. E. coli S. aureus, and Enterococcus were the most common organisms. Another study conducted on 255 patients having advanced cancer in order to develop guidelines for the use of antimicrobials in PC reported that the most frequent infections were urinary tract infections, followed by respiratory tract and skin/subcutaneous tissue infections. It was further reported that the use of antimicrobials did not improve survival yet provided effective symptom control (16). Similar to our results, Reinbolt et al.(12) reported that $\mathrm{E}$. coli was the most common urinary tract infection. The most frequent urinary tract organisms were E. coli. Also, that patients' survival was not affected by the presence of infection or use of antimicrobials and that, despite improving symptoms in most of the patients with urinary tract infections, antimicrobial use was less successful in symptom control in respiratory tract, 
oral/pharyngeal, skin/subcutaneous tissue, or blood infections. Yamada et al. (17) reported that MR-CoNS are the most common microorganisms in blood cultures and most patients are malignant. In studies, CoNS is a major cause of nosocomial bacteremia and septicemia, especially for the patients who have been reported to be immune deficiency and malignancy $(11,17)$. Patients with prosthetic devices, intravascular catheters, or other implanted foreign bodies are at particular risk of CoNS infection (17). In accordance with the literature, we assume that the high rate of MR-CoNS isolation in blood cultures is due to the patients in terminal period in our study and the frequent use of urinary catheter and intravenous catheter.

As additionally reported by Reinbolt et al. (12), blood infections manifest with more dramatic symptoms such as fever, disorientation, and hypotension compared to urinary tract and wound infections. In fact, urinary tract infections are mostly asymptomatic and usually overlooked due to often atypical presentations (18). We also believe that patients who had growth in their blood cultures were referred to the ICU upon patients' or families' requests for a more effective therapy due to the observation of more dramatic symptoms and that urinary tract infections were relatively more common in those who died as they were not referred to the ICU because of the atypical course of these infections.

In our study, the rate of wound culture in PD, $\mathrm{DM}$ and $\mathrm{PU}$ patients was significantly higher than that of wound culture in cancer patients $(p<0.05)$. The fact that wound culture growth is less common in cancer patients and more common in patients with PD is consistent with the literature. In fact, it is acknowledged that the disease course is usually shorter in cancer, whereas in neurological diseases such as PD, the decline in functional capacity has a slow progression with longer patient life span; however, patients become gradually dependent. After the diagnosis of cancer, the prognosis becomes worse with a shortened life span $(19,20)$. Therefore, $\mathrm{PU}$ was less observed in cancer patients with less common growth in wound cultures compared to the higher occurrence of PU and wound infections in patients with $\mathrm{PD}$, whereby immobilizatio was also more frequent with a longer disease course. Thomsen et al. (21) compared diabetic patients to non-diabetic patients and reported that diabetes increased the risk of community-acquired bacteremia and was associated with poor prognosis. Consistent with the literature, our findings suggest that DM increases susceptibility to infections, a probable reason explaining the observation of high frequency of growth in wound cultures of DM patients in our study.

In patients with HB, PEG, and tracheostomy, growth in TA culture was significantly more common $(p<0.05)$. At present, the insertion of gastrostomy and tracheostomy tube is a common practice in cases of hypoxic encephalopathy, especially in those whom rapid clinical improvement is not expected $(22,23)$. By providing viruses and bacteria a direct entry to the lower respiratory tract, tracheostomy cannulas are known to predispose patients to respiratory tract infections and additionally lead to a local inflammatory reaction, further increasing the risk for infection $(24,25)$. Furthermore, patients with chronic tracheostomy are exposed to bacterial colonization of the respiratory tract, a risk factor for respiratory tract infections (25).

In conclusion, we mostly observed urinary tract infection in geriatric patients receiving $\mathrm{PC}$ and noted TA growth to be more common in diabetic patients with tracheostomy and PEG. Therefore, we believe an effective symptom control could be achieved in patients receiving $P C$ with the early detection of urinary tract infections and of pulmonary infections in diabetic patients with tracheostomy and PEG. As a limited number of studies exist both in our country and in the literature, further studies are warranted to support these findings.

\section{ACKNOWLEDGEMENTS}

None declared

\section{Conflicts of interest}

None declared 


\section{REFERENCES}

1. Allareddy V, Rampa S, Nalliah RP, et al. Prevalence and predictors of gastrostomy tube and tracheostomy placement in anoxic/hypoxic ischemic encephalopathic survivors of in-hospital cardiopulmonary resuscitation in the United States. PloS One 2015;10(7):e0132612. (PMID:26197229).

2. Caterino JM. Evaluation and management of geriatric infections in the emergency department. Emerg Med Clin North Am 2008;26(2):319-43, viii. (PMID:18406977).

3. Cheng HW, Sham MK, Chan KY. Emergence of vancomycin-resistant enterococci in the palliative care setting-how to strike the right balance in infection control measures? J Pain Symptom Manage 2014;47(1):e7-8. (PMID:24211119).

4. Christensen K, Doblhammer G, Rau R, Vaupel JW. Ageing populations: the challenges ahead. Lancet 2009;374(9696):1196-208. (PMID:19801098)

5. Connor SR, Bermedo MC. (Eds). Global atlas of palliative care at the end of life. London: Worldwide Palliative Care Alliance; 2014. [Internet] Available from: http://www.who.int/nmh/Global_Atlas_of_Palliative_ Care.pdf. Accessed: 06.23.2018.

6. Davies E, Higginson I (Eds). Palliative care. The solid facts. [Internet] Available from: http://www.euro. who.int/_data/assets/pdf_file/0003/98418/E82931. pdf?ua=1. Accessed: 05.07.2018.

7. Katz MJ, Roghmann MC. Healthcare-associated infections in the elderly: What's new. Curr Opin Infect Dis 2016;29(4):388-93. (PMID:27306562).

8. Lusuardi M, Capelli A, Cerutti CG, Gnemmi I, Zaccaria S, Donner CF. Influence of clinical history on airways bacterial colonization in subjects with chronic tracheostomy. Respir Med 2000;94(5):436-40. (PMID:17132052).

9. Lynn J, Adamson DM. Living well at the end of life. Adapting health care to serious chronic illness in old age. 2003. [Internet] Available from: https://www.rand. org/content/dam/rand/pubs/white_papers/2005/ WP137.pdf. Accessed: 05.07.2018.

10. Mathers CD, Loncar D. Projections of global mortality and burden of disease from 2002 to 2030. PLoS Med 2006;3(11):e442. (PMID:17132052)

11. Pereira J, Watanabe $S$, Wolch $G$. A retrospective review of the frequency of infections and patterns of antibiotic utilization on a palliative care unit. J Pain Symptom Manage 1998;16(6):374-81. (PMID:9879162).

12. Pignatti $P$, Balestrino $A$, Herr $C, B a l s R$, Moretto D, Corradi $M$. et al. Tracheostomy and related host-pathogen interaction are associated with airway inflammation as characterized by tracheal aspirate analysis. Respir Med 2009;103(2):201-8. (PMID:18980836).

13. Reinbolt RE, Shenk AM, White PH, Navari RM. Symptomatic treatment of infections in patients with advanced cancer receiving hospice care.
J Pain Symptom Manage 2005;30(2):175-82. (PMID:16125033).

14. Ribera Casado JM. Geriatrics and palliative care: some reflections. Rev Esp Geriatr Gerontol 2013;48(2):89-93. (PMID:23159775).

15. Rosenberg JH, Albrecht JS, Fromme EK, Noble BN, McGregor JC, Comer AC, et al. Antimicrobial use for symptom management in patients receiving hospice and palliative care: a systematic review. J Palliat Med 2013;16(12):1568-74. (PMID:24151960).

16. Schonenberger S, Al-Suwaidan F, Kieser M, Uhlmann $\mathrm{L}$, Bosel J. The SETscore to predict tracheostomy need in cerebrovascular neurocritical care patients. Neurocrit Care 2016;25(1):94-104. (PMID:26842719).

17. Thomsen RW, Hundborg HH, Lervang HH, Johnsen SP, Schønheyder HC, Sørensen HT. Diabetes mellitus as a risk and prognostic factor for communityacquired bacteremia due to enterobacteria: a 10-year, population-based study among adults. Clin Infect Dis 2005;40(4):628-31. (PMID:15712091).

18. Unroe KT, Meier DE. Research priorities in geriatric palliative care: policy initiatives. J Palliat Med 2013;16(12):1503-8. (PMID:24147877).

19. Vitetta L, Kenner D, Sali A. Bacterial infections in terminally ill hospice patients. J Pain Symptom Manage 2000;20(5):326-34. (PMID:11068154).

20. White $\mathrm{PH}$, Kuhlenschmidt $\mathrm{HL}$, Vancura BG, Navari RM. Antimicrobial use in patients with advanced cancer receiving hospice care. J Pain Symptom Manage 2003;25(5):438-43. (PMID:12727041).

21. WHO definition of palliative care. [Internet] Available from: http://www.who.int/cancer/palliative/definition/ en/. Accessed: 06.23.2018.

22. World Health Organization. Better Palliative Care for Older People. Copenhagen: WHO; 2004. [Internet] Available from: http://www.euro.who.int/_data/ assets/pdf_file/0009/98235/E82933.pdf. Accessed: 07.06.2018.

23. World Health Organization. Planning and implementing palliativecareservices:aguideforprogrammemanagers. 2016. [Internet] Available from: http://apps.who.int/ iris/bitstream/handle/10665/250584/9789241565417eng.pdf?sequence=1. Accessed: 06.23.2018.

24. Yajima $R$, Ise $Y$, Wako $T$, et al. A retrospective study of risk factors for infection in cancer patients receiving specialist palliative care. J Nippon Med Sch 2013;80(6):481-5. (PMID:24419723).

25. Yamada K, Namikawa $H$, Fujimoto $H$, et al. Nakaie K, Takizawa E, Okada Y, et al. Clinical Characteristics of Methicillin-resistant Coagulase-negative Staphylococcal Bacteremia in a Tertiary Hospital. Intern Med 2017;56(7):781-5. (PMID:28381743). 